\title{
Roles of Oxygen Radical Production and Lipid Peroxidation in the Cytotoxicity of Cephaloridine on Cultured Renal Epithelial Cells (LLC-PK 1 )
}

\author{
Ken-ichi KIYOMIYA, Naoko MATSUSHITA ${ }^{1)}$, Saburou MATSUO and Masaru KUREBE \\ Department of Toxicology, School of Veterinary Medicine, Osaka Prefecture University, 1-1 Gakuen-cho, Sakai, Osaka 599-8531 and \\ ${ }^{1}$ Pharmaceutical Research Center, Meiji Seika Kaisha Ltd., 760 Morooka-cho, Kohoku-ku, Yokohama 222-8567, Japan
}

(Received 23 March 2000/Accepted 20 May 2000)

ABSTRACT. To clarify the mechanism of cephalosporin nephrotoxicity, the cytotoxic effects of cephaloridine (CER), a nephrotoxic cephalosporin antibiotic, on the pig kidney proximal tubular epithelial cell line (LLC-PK 1 ) were studied in culture. CER increased the content of hydrogen peroxide and decreased the activity of catalase in the treated cells, followed by an increase in the content of lipid peroxide and decreases in both glutathione peroxidase activity and in the non-protein sulfhydryl content. The levels of NADPH-dependent hydrogen peroxide and superoxide anion production by microsomes prepared from LLC-PK 1 cells, and by NADPH-cytochrome P-450 reductase purified from the rat renal cortex were significantly increased by paraquat. The production of these molecules was antagonized by $p$-chloromercuribenzoate, an inhibitor of NADPH-cytochrome P-450 reductase. On the other hand, CER did not significantly affect the production of hydrogen peroxide or superoxide anions. These results suggested that the cytotoxic effect of CER on cultured LLC-PK ${ }_{1}$ cells was due to the increases in hydrogen peroxide and lipid peroxide levels and not microsomal oxygen radical production, and that the mechanism of this cytotoxicity is very different from that of paraquat which induces microsomal oxygen radical production. KEY wORDS: cephaloridine, lipid peroxidation, LLC-PK $_{1}$ cell, nephrotoxicity, oxygen radical.

J. Vet. Med. Sci. 62(9): 977-981, 2000

The nephrotoxic cephalosporin antibiotic cephaloridine (CER) causes damage to renal proximal tubular epithelial cells in proportion to the dose administered and the accumulated concentration in the kidneys [2, 18, 21, 22, 24]. There have been many investigations to elucidate the mechanism of its nephrotoxicity, and the cytotoxic effect was suggested to be due to increased lipid peroxidation, which leads to the observed histopathological changes $[7,8,11,12,19]$.

Kuo et al. [12] assumed that the reduced CER induced by microsomal NADPH-dependent cytochrome P-450 reductase results in the production of free radicals through redox cycling in the same manner as paraquat. Cojocel et al. $[7,8]$ also demonstrated that superoxide anion and hydrogen peroxide are produced by microsomes of the kidney cortex, and that the cytotoxicity of CER was decreased by antioxidant treatment in slices of the kidney cortex. However, as these results were obtained with a comparatively high dose of the antibiotic, it is necessary to determine whether the primary action of CER at the cytotoxic dose is induction of microsomal production of free radicals in renal proximal tubular epithelial cells.

This study was performed to investigate in detail the relationships among the microsomal NADPH-dependent production of oxygen radicals, the activities of antioxidant and scavenging enzymes, and intracellular lipid peroxide content in cultured LLC-PK 1 cells during after treatment with CER.

\section{MATERIALS AND METHODS}

Reagents: Cephaloridine (CER), scopoletin, epinephrine, $p$-chloromercuribenzoate (PCMB), peroxidase (horseradish, type II), catalase (bovine liver), superoxide dismutase (SOD; bovine erythrocytes) and xanthine oxidase (buttermilk, grade
III) were obtained from Sigma Chemical Co. (St. Louis, MO, U.S.A.). NADPH was from Boehringer Mannheim (Mannheim, Germany) and 2',7'-dichlorofluorescein diacetate (DCFDA) was from Eastman Kodak (Rochester, NY, U.S.A.). Other chemicals and reagents used were of high commercial grade.

Effects on cultured cells: LLC-PK 1 cells (American Type Culture Collection, CRL 1392, passage 196) were obtained from Flow Laboratories (Rockville, MD, U.S.A.). The cells were inoculated at a density of $1.5 \times 10^{5}$ cells into $35 \mathrm{~mm}$ tissue culture dishes in $1.5 \mathrm{~m} /$ of Dulbecco's modified Eagle's medium/Ham's F12 medium (1:1) containing growth supplements [20] and 5\% fetal calf serum (Gibco, Grand Island, NY, U.S.A.) in the absence of antibiotics, and cultivated at $37^{\circ} \mathrm{C}$ in an atmosphere of $5 \% \mathrm{CO}_{2}$ in air until confluent $(4-5$ days). The confluent cells were treated with 0.5 or $1.0 \mathrm{mM}$ CER in fresh culture medium. The treated cells were harvested for biochemical analyses at various predetermined time points.

Biochemical analyses: The harvested cells were washed with ice-cold phosphate-buffered saline (PBS) and sonicated in an adequate volume of PBS. These suspensions were used for assays. Cellular non-protein sulfhydryl was measured with Ellman's reagent after deproteinization according to the method of Beutler et al. [4]. Cellular lipid peroxide was determined using a Detamina LPO kit (Kyowa Co., Tokyo, Japan). Cellular hydrogen peroxide was determined by the scopoletin method according to Andreae [1]. Cellular glutathione peroxidase and catalase activities were assayed according to the methods of Carmagnol et al. [6] and Decker [10], respectively. Cellular SOD activity was assayed from the oxidation rate of epinephrine to adrenochrome according to the method of Misra and Fridovich [15]. Cellular protein 
was determined using a Bio-Rad Test kit (Bio-Rad Laboratory, Richmond, CA, U.S.A.).

Cellular oxygen radical production: The cellular oxygen radical production was monitored using DCFDA as a probe according to the methods of Bass et al. [3] and Scott et al. [17]. The confluent LLC-PK 1 cells were incubated at a density of $10^{6}$ cells $/ \mathrm{m} l$ in Hanks' balanced salt solution (HBSS) containing $5 \mu \mathrm{M} \mathrm{DCFDA}$ at $37^{\circ} \mathrm{C}$ for $20 \mathrm{~min}$. The DCFDAloaded cells were washed with ice-cold HBSS to remove the extracellular probe and resuspended in fresh HBSS to a final concentration of $10^{6}$ cells $/ \mathrm{ml}$. CER was added to the suspension and the fluorescence of the oxidized probe was measured with excitation and emission wavelengths of $480 \mathrm{~nm}$ and $530 \mathrm{~nm}$, respectively, for $0-60 \mathrm{~min}$ at $37^{\circ} \mathrm{C}$. Xanthine oxidase $(6 \mathrm{mU} / \mathrm{m} l)$ with $1 \mathrm{mM}$ hypoxanthine was used as a positive control.

Oxygen radical production by microsomes: The confluent LLC-PK $_{1}$ cells were homogenized in ice-cold $50 \mathrm{mM}$ Tris$\mathrm{HCl}$ buffered ( $\mathrm{pH} 7.5) 0.25 \mathrm{M}$ sucrose and centrifuged at 600 $\times \mathrm{g}$ for $10 \mathrm{~min}$. After centrifugation of the supernatant at $10,000 \times \mathrm{g}$ for $20 \mathrm{~min}$, the resulting supernatant was again centrifuged at $105,000 \times \mathrm{g}$ for $60 \mathrm{~min}$. The pellet was washed three times with $0.1 \mathrm{M}$ potassium phosphate buffer $(\mathrm{pH} 7.5)$ and suspended in the same buffer to a concentration of $10 \mathrm{mg}$ protein $/ \mathrm{m} l$.

The microsomal production of superoxide anion in the presence or absence of CER was measured using the formed adrenochrome as an indicator, according to the method of Cadenas et al. [5]. The reaction mixture contained microsomes ( $42 \mu \mathrm{g}$ of protein), $1 \mathrm{mM}$ epinephrine, $0.35 \mathrm{mM}$ NADPH and various concentrations of CER or other reagents in $1 \mathrm{~m} l$ of $0.1 \mathrm{M}$ potassium phosphate buffer $(\mathrm{pH}$ 7.5) were incubated at $30^{\circ} \mathrm{C}$. Ten minutes later, the adrenochrome yield was determined from the change of absorbance at $485 \mathrm{~nm}$.

The microsomal production of hydrogen peroxide in the presence or absence of CER was measured with oxidized scopoletin as an indicator according to the method of Walker and Shah [23]. The reaction mixtures containing microsomes (422 $\mu \mathrm{g}$ of protein), $200 \mu \mathrm{g} / \mathrm{m} l$ of peroxidase, $1.25 \mu \mathrm{M} \mathrm{sco-}$ poletin, $0.35 \mathrm{mM}$ NADPH and various concentrations of CER or other agents in $2 \mathrm{~m} l$ of $0.1 \mathrm{M}$ potassium phosphate buffer ( $\mathrm{pH} \mathrm{7.5)} \mathrm{were} \mathrm{incubated} \mathrm{at} 30^{\circ} \mathrm{C}$. Ten minutes later, the amount of hydrogen peroxide produced was determined from the change in fluorescence with excitation and emission wavelengths of $385 \mathrm{~nm}$ of $460 \mathrm{~nm}$, respectively.

Oxygen radical production by $N A D P H$-cytochrome $P-450$ reductase: Kidney cortical tissues were isolated from the kidneys of male Wistar rats weighing $200 \mathrm{~g}$ (Charles River Co., Yokohama, Japan), and the microsome fractions were prepared from the tissues by the procedures described above. NADPH-cytochrome $\mathrm{P}-450$ reductase was purified from the microsome fractions according to the method of Yasukochi and Masters [26]. The enzyme fraction used had a specific activity of about $1.7 \mu$ moles of cytochrome $\mathrm{c}$ reduced $/ \mathrm{mg}$ protein/min. The effects of CER and paraquat on the superoxide anion production by NADPH-cytochrome P-450 reductase were observed by the same procedures as described for the microsome fraction.

Statistical analysis: Data are expressed as means \pm SD. Results were analyzed by Student's $t$-test.

\section{RESULTS}

Effects on hydrogen peroxide, reduced glutathione, lipid peroxide, catalase, glutathione peroxidase and superoxide dismutase in cultured cells: On day 1 after addition of 0.5 or $1.0 \mathrm{mM}$ CER to cultured LLC-PK 1 cells, cellular hydrogen peroxide level increased in a dose-dependent manner (Fig. 1). The increase was much greater on day 2 than on day 1 . Cellular contents of non-protein sulfhydryl (mainly reduced glutathione) increased transiently on day 1 after treatment with $0.5 \mathrm{mM}$ CER, but thereafter decreased markedly (Fig. 1), while the content of lipid peroxide was increased significantly on day 2 and markedly on day 3 (Fig. 1) with cell necrosis. Cellular catalase activity decreased in a dose- and time-dependent manner from day 1 after treatment with 0.5 or $1.0 \mathrm{mM} \mathrm{CER} \mathrm{(Fig.} \mathrm{2).} \mathrm{Cellular} \mathrm{glutathione} \mathrm{peroxidase}$ activity increased transiently at $0.5 \mathrm{mM}$ CER on day 1 but thereafter decreased on day 2 . At a concentration of $1.0 \mathrm{mM}$, the activity decreased from day 1 and this effect was marked on day 2. Cellular SOD activity showed a tendency to increase with higher CER concentrations on day 1 , but on day 2 no significant difference was observed between control and treated cells.

Cellular axygen radical production: An immediate effect of CER on cellular radical production was observed with DCFDA-preloaded LLC-PK ${ }_{1}$ cells. CER caused a slight reduction of the rate of fluorescence increase indicating radical production in the cells and this effect was dose-dependent, while xanthine oxidase and hypoxanthine caused increased fluorescence intensity (Fig. 3).

Oxygen radical production by microsomes: CER did not significantly affect the rate of adrenochrome formation indicating superoxide anion production in the microsomes prepared from LLC-PK 1 cells, but paraquat significantly increased adrenochrome formation (Table 1). This effect of paraquat was prevented by addition of PCMB, an inhibitor of NADPH-cytochrome $\mathrm{P}-450$ reductase $[13,25]$, or SOD. CER and paraquat showed similar effects on the hydrogen peroxide production in microsomes as observed on adrenochrome formation. The paraquat-induced increase in hydrogen peroxide level was prevented by addition of $P C M B$ or catalase.

Oxygen radical production by NADPH-cytochrome $P-450$ reductase: The rate of NADPH-cytochrome $\mathrm{P}-450$ reductase-generated adrenochrome formation was not significantly affected by 1 or $10 \mathrm{mM}$ CER, but $0.1 \mathrm{mM}$ paraquat induced marked acceleration (Table 2).

\section{DISCUSSION}

Some investigators have suggested that the nephrotoxicity of CER is due to the intracellular increase of lipid peroxide 
Hydrogen proxide

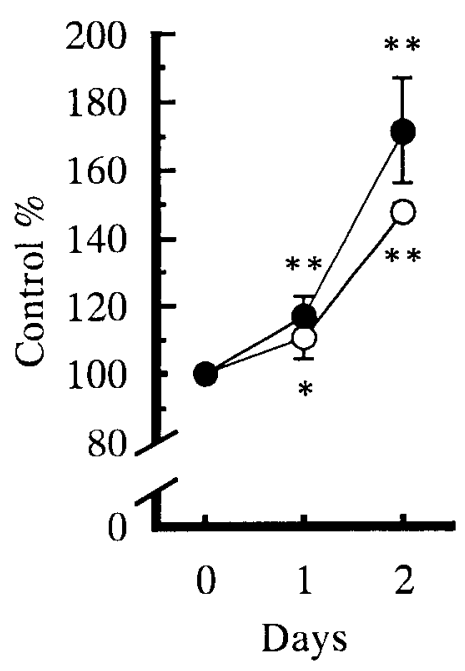

Lipid peroxide

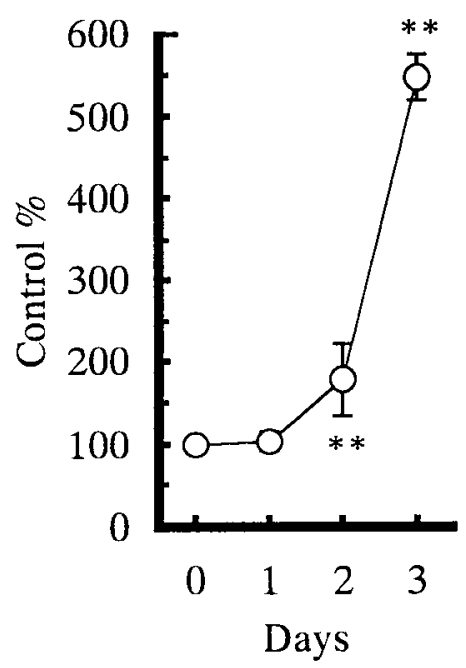

Glutathione

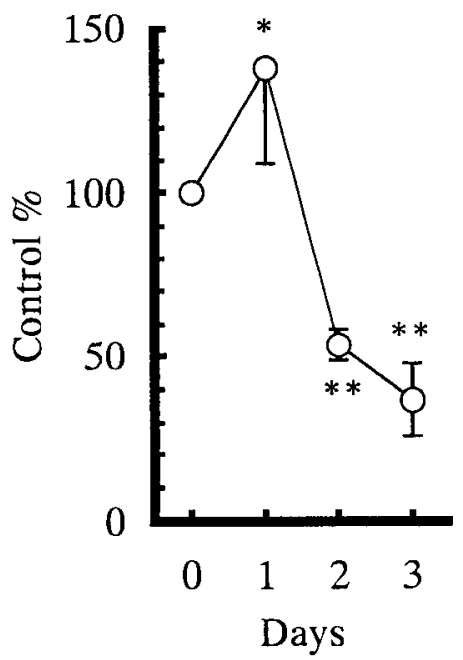

Fig. 1. Effects of CER on the contents of hydrogen peroxide, lipid peroxide and non-protein sulfhydryl in cultured LLC-PK 1 cells. The cells were cultured until confluence and then treated with CER at concentrations of $0.5 \mathrm{mM}(O)$ and $1.0 \mathrm{mM}(\bullet)$. The results are shown as percentages of the control and represent the means \pm SD of 3 experiments. * and ${ }^{* *}$ indicate significant differences from control value; $P<0.05$ and $P<0.01$, respectively.

Catalase

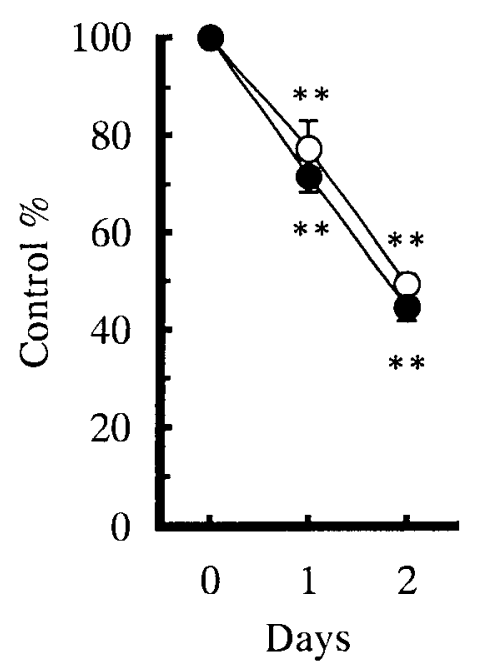

Glutathione peroxidase

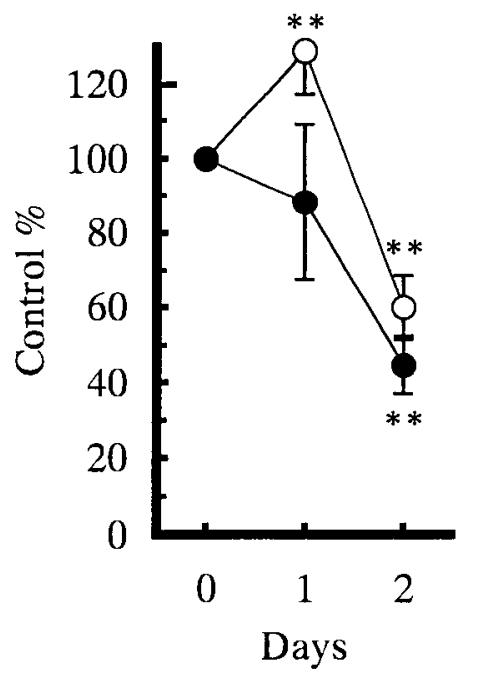

Superoxide dismutase

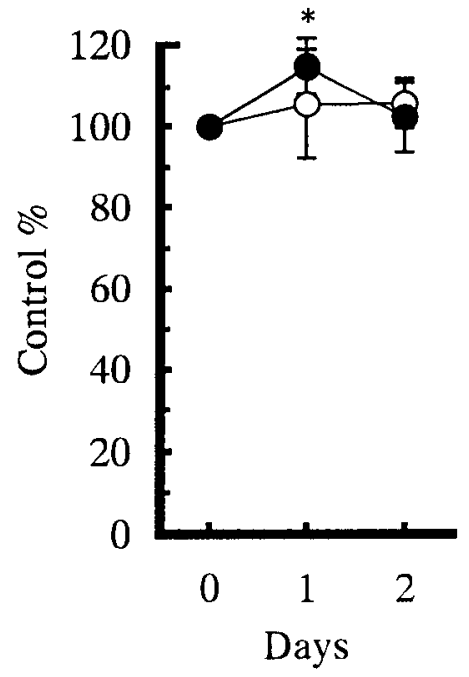

Fig. 2. Effects of CER on the catalase, glutathione peroxidase, and superoxide dismutase activities in cultured LLC-PK 1 cells. The cells were cultured until confluence and then treated with CER at concentrations of $0.5 \mathrm{mM}(O)$ and $1.0 \mathrm{mM}(\bullet)$. The results are shown as percentages of the control and represent the means \pm SD of 3 experiments. ${ }^{*}$ and ${ }^{* *}$ indicate significant differences from control value; $P<0.05$ and $P<0.01$, respectively.

$[7,8,11,12,19]$, but it is not fully understood how intracellular lipid peroxides are excessively induced in the renal cells treated with CER. Therefore, we first examined which biochemical parameters were altered before the increase in intracellular lipid peroxide level in LLC-PK 1 cells treated with a cytotoxic dose of CER.
The intracellular lipid peroxide content was increased on day 2 and to a much greater extent on day 3 after treatment with $0.5 \mathrm{mM}$ CER, which was accompanied with decreases in reduced glutathione content and glutathione peroxidase activity and also an increase in hydrogen peroxide content. However, the intracellular catalase activity decreased signif- 


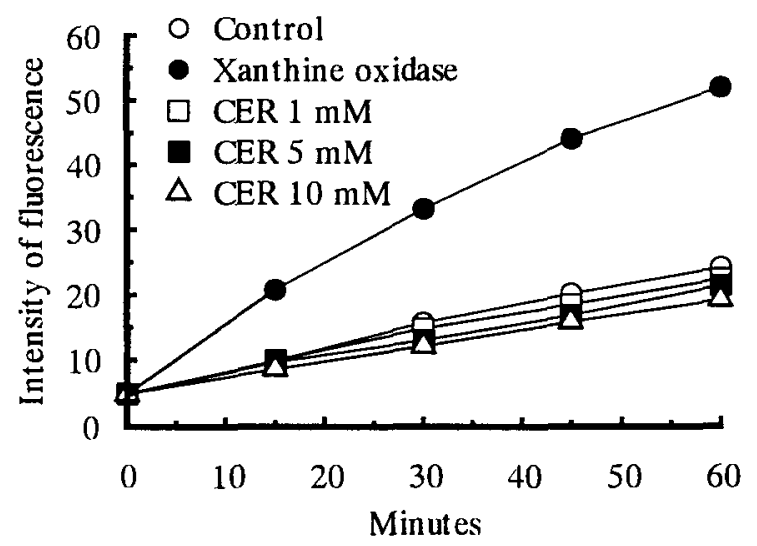

Fig. 3. Effects of CER on the immediate cellular radical production in cultured $L L C-P_{1}$ cells. The cells were loaded with $2^{\prime}, 7^{\prime}$ dichlorofluorescein diacetate, as described in "Materials and Methods" and then treated with CER (1-10 mM) or xanthine oxidase with hypoxanthine (positive control). The fluorescence of the oxidized probe was measured with excitation and emission wavelengths of $480 \mathrm{~nm}$ and $530 \mathrm{~nm}$, respectively, for $0-60 \mathrm{~min}$.

icantly from day 1 , before these changes occurred. These results suggested that CER increases the intracellular hydrogen peroxide level and decreases the scavenging activities of catalase and glutathione peroxidase and also the intracellular content of reduced glutathione, followed by an increase in lipid peroxide level that leads to cell damage. The findings indicating that CER at a concentration of $0.5 \mathrm{mM}$ elevated the level of intracellular hydrogen peroxide from day 1 and the level of lipid peroxide from day 2 are consistent with the observations that CER at the same concentration from day 1 decreased both the activity of catalase, which scavenges hydrogen peroxide, and that of glutathione peroxidase, which scavenges lipid peroxide and hydrogen peroxide, from day 2 . The transient increases in glutathione peroxidase activity and glutathione content on day 1 after treatment with $0.5 \mathrm{mM}$ CER may have been induced to scavenge the lipid peroxide produced at early stages. Although the precise biochemical mechanism of decrease in the radical scavenging activities by treatment of LLC-PK 1 cells with CER is still unknown, there are several possible explanations for the observed results. Since CER-induced decrease in the radical scavenging activities in the cells was time-dependent, CER may induce decrease in the activities through formation of active inhibitors due to bioactivation of CER by cytochrome $\mathrm{P}-450$ $[14,16]$ or through gradual inactivation of the enzyme by CER or its metabolites.

Kuo et al. [12] suggested that the pyridinium side-chain on the $\beta$-lactam ring of CER may undergo one-electron reduction by microsomal NADPH-cytochrome $\mathrm{P}-450$ reductase in the same manner as paraquat, a bipyridinium compound. Then, the oxygen free radicals produced could lead to glutathione depletion and lipid peroxidation resulting in nephrotoxicity. However, the postulated involvement of the pyridinium side-chain of CER in redox cycling is weakened by the observation that cefalotin, which is structurally identi-
Table 1. Effects of CER and paraquat on the production of superoxide anion and hydrogen peroxide by the microsomes prepared from LLC-PK, cells

\begin{tabular}{ccc}
\hline \multicolumn{1}{c}{ Addition } & $\begin{array}{c}\text { Superoxide anion } \\
\text { production }^{\text {a) }}\end{array}$ & $\begin{array}{c}\text { Hydrogen } \\
\text { peroxide } \\
\text { production }\end{array}$ \\
\hline No addition & $<1.0$ & $22.3 \pm 0.7$ \\
CER $1 \mathrm{mM}$ & $<1.0$ & $22.1 \pm 0.8$ \\
$\quad 10 \mathrm{mM}$ & $<1.0$ & $39.1 \pm 1.6$ \\
Paraquat $0.1 \mathrm{mM}$ & $33.2 \pm 2.2$ & $158.1 \pm 0.9$ \\
+ PCMB $0.1 \mathrm{mM}$ & $<1.0$ & $28.0 \pm 1.3$ \\
+ SOD $50 \mathrm{U} / \mathrm{ml}$ & $<1.0$ & - \\
+ Catalase $100 \mu \mathrm{g} / \mathrm{m} l$ & - & $76.5 \pm 2.6$ \\
\hline
\end{tabular}

Values are shown as nmoles $/ \mathrm{min} / \mathrm{mg}$ protein and represent the means \pm SD of 3 experiments. ${ }^{\text {a) }}$ Production of superoxide anion expresses as formed adrenochrome.

Table 2. Effects of CER and paraquat on the superoxide anion production by NADPH-cytochrome $\mathrm{P}-450$ reductase purified from the rat renal cortex

\begin{tabular}{cc}
\hline \multicolumn{1}{c}{ Addition } & $\begin{array}{c}\text { Superoxide anion } \\
\text { production }^{\text {a) }}\end{array}$ \\
\hline No addition & $27.9 \pm 11.2$ \\
CER $1 \mathrm{mM}$ & $30.1 \pm 14.1$ \\
$10 \mathrm{mM}$ & $28.5 \pm 7.3$ \\
Paraquat $0.1 \mathrm{mM}$ & $636.1 \pm 14.1$ \\
\hline
\end{tabular}

Values are shown as nmoles $/ \mathrm{min} / \mathrm{mg}$ protein and represent the means \pm SD of 3 experiments. a) Production of superoxide anion expresses as formed adrenochrome.

cal to CER except that it lacks the pyridinium side chain, induces lipid peroxidation in rat renal cortical slices [9]. Furthermore, we did not allow increases in superoxide anion production by the microsomes prepared from $\mathrm{LLC}^{-\mathrm{PK}_{1} \text { cells }}$ or NADPH-cytochrome P-450 reductase purified from the microsomes of rat renal cortex in the presence of a cytotoxic (1 $\mathrm{mM})$ or excess dose $(10 \mathrm{mM})$ of CER and an excess of NADPH. On the other hand, paraquat significantly increased the levels of superoxide anion and hydrogen peroxide production, and these effects of paraquat were prevented by addition of PCMB, an inhibitor of NADPH-cytochrome P450 reductase $[13,25]$, or superoxide scavenger enzymes such as SOD and catalase. Furthermore, CER did not affect the immediate production of intracellular oxygen radicals in the DCFDA-preloaded LLC-PK 1 cells. These observations suggested that CER does not undergo one-electron reduction by the microsomal NADPH-cytochrome P-450 reductase and does not induce intracellular superoxide production by redox cycling. The CER-induced increase in intracellular superoxide level may be based on decrease in the radical scavenging activity rather than a primary action of this antibiotic.

In conclusion, our results indicated that CER does not undergo single-electron reduction by microsomal NADPHcytochrome $\mathrm{P}-450$ reductase and is unable to produce superoxide anion by redox cycling. The cytotoxic effects of CER on cultured LLC-PK 1 cells may be due to increases in the lev- 
els of hydrogen peroxide and lipid peroxide by a redox cycling-independent mechanism that decreases the scavenging activities of catalase and glutathione peroxidase and also intracellular contents of reduced glutathione. The cytotoxic mechanism of action of CER is very different from that of paraquat, which induces microsomal radical production.

\section{REFERENCES}

1. Andreae, W.A. 1955. A sensitive method for the estimation of hydrogen peroxide in biological materials. Nature (Lond.) 175: 859-860

2. Atkinson, R. M., Caisey, J. D., Currie, J. P., Middleton, T. R., Pratt, D. A. H., Sharpe, H. M. and Tomich, E. G. 1966. Subacute toxicity of cephaloridine to various species. Toxicol. Appl. Pharmacol. 8: 407-428.

3. Bass, D. A., Parce, J. W., Dechatelet, L. R., Szejda, P., Seeds, M. C. and Thomas, M. 1983. Flow cytometric studies of oxidative product formation by neutrophils: A graded response to membrane stimulation. J. Immunol. 130: 1910-1918.

4. Beutler, G. C., Duron, O. and Kelley, B. M. 1963. Improvement method for the determination of blood glutathione. J. Lab. Clin. Med. 61: 882-888.

5. Cadenas, E., Boveris, A., Ragan, C. I. and Stoppani, A. O. 1977. Production of superoxide radicals and hydrogen peroxide by NADH-ubiquinone reductase and ubiquinol-cytochrome $c$ reductase from beef-heart mitochondria. Arch. Biochem. Biophys. 180: 248-257.

6. Carmagnol, F., Sinet, P. M. and Jerome, H. 1983. Seleniumdependent and non-selenium-dependent glutathione peroxidases in human tissue extracts. Biochim. Biophys. Acta 759: 49-57.

7. Cojocel, C., Hannemann, J. and Baumann, K. 1985. Cephaloridine-induced lipid peroxidation initiated by reactive oxygen species as a possible mechanism of cephaloridine nephrotoxicity. Biochim. Biophys. Acta 834: 402-410.

8. Cojocel, C., Laeschke, K. H., Inselmann, G. and Baumann, K. 1985. Inhibition of cephaloridine-induced lipid peroxidation. Toxicology 35: 295-305.

9. Cojocel, C., Gottsche, U., Tolle, K. L. and Baumann, K. 1988. Nephrotoxic potential of first-, second-, and third-generation cephalosporins. Arch. Toxicol. 62: 458-464

10. Decker, L. A. 1977. Catalase. pp. 63-65. In: Worthington Enzymes, Enzyme Reagents, Related Biochemicals (Decker, L. A. ed.), Worthington Biochemical Co., Freefold,

11. Goldstein, R. S., Pasino, D. A., Hewitt, W. R. and Hook, J. B. 1986. Biochemical mechanisms of cephaloridine nephrotoxicity: Time and concentration dependence of peroxidative injury. Toxicol. Appl. Pharmacol. 83: 261--270
12. Kuo, C.-H., Maita, K., Sleight, S. D. and Hook, J. B. 1983. Lipid peroxidation: A possible mechanism of cephaloridine-induced nephrotoxicity. Toxicol. Appl. Pharmacol. 67: 78-88.

13. Masters, B. S. and Kamin, H. 1965. Studies on the mechanism of microsomal triphosphopyridine nucleotide-cytochrome $\mathrm{c}$ reductase. J. Biol. Chem. 240: 921-931.

14. McMurtry, R. J. and Mitchell, J. R. 1977. Renal and hepatic necrosis after metabolic activation of 2-substituted furans and thiophenes, including furosemide and cephaloridine. Toxicol. Appl. Pharmacol. 42: 285-300

15. Misra, H. P. and Fridovich, I. 1972. The role of superoxide anion in the autoxidation of epinephrine and simple assay for superoxide dismutase. J. Biol. Chem. 247: 3170-3175.

16. Mitchell, J. R., McMurtry, R. J., Statham, C. N. and Nelson, S. D. 1977. Molecular basis for several drug-induced nephropathies. Am. J. Med. 62: 518-526.

17. Scott, J. A., Homcy, C. J., Khaw, B.-A. and Rabito, C. A. 1988 Quantitation of intracellular oxidation in a renal epithelial cell line. J. Free Rad. Biol. Med. 4: 79-83.

18. Silverblatt, F., Harrison, W. O. and Turck, M. 1973. Nephrotoxicity of cephalosporin antibiotics in experimental animals. $J$. Infect. Dis. 128: S367-S372.

19. Suzuki, Y. and Sudo, J.-I. 1990. Lipid peroxidation and generations of oxygen radicals induced by cephaloridine in renal cortical microsomes of rats. Jpn. J. Pharmacol. 52: 223-243.

20. Taub, M. and Sato, G. 1980. Growth functional primary cultures rat kidney epithelial cells in defined medium. J. Cell Physiol. 105: 369-378.

21. Tune, B. M. 1975. Relationship between the transport and toxicity of cephalosporins in the kidney. J. Infect. Dis. 132:189-194

22. Tune, B. M., Wu, K. Y. and Kempson, R. L. 1977. Inhibition of transport and prevention of toxicity of cephaloridine in the kidney: Dose-responsiveness of the rabbit and the guinea pig to probenecid. J. Pharmacol. Exp. Ther. 202: 466-471.

23. Walker, P. D. and Shah, S. V. 1987. Gentamicin enhanced production of hydrogen peroxide by renal cortical mitochondria. Am. J. Physiol. 253: C495-C499.

24. Welles, J. S., Gibson, W. R., Harris, P. N., Small, R. M. and Anderson, R. C. 1965. Toxicity, distribution and excretion of cephaloridine in laboratory animals. Antimicrob. Agents Chemother. 65: 863-869.

25. Williams, C. H. and Kamin, H. 1962. Microsomal triphosphopyridine nucleotide-cytochrome $\mathrm{c}$ reductase of liver. J. Biol. Chem. 237: 587-595

26. Yasukochi, Y. and Masters, B. S. 1976. Some properties of a detergent-solubilized NADPH-cytochrome $c$ (cytochrome P450 ) reductase purified by biospecific affinity chromatography. J. Biol. Chem. 251: 5337-5344. 